\title{
Rancang Bangun Turbin Vortex Dengan Casing Berpenampang Lingkaran Yang Menggunakan Sudu Diameter 46 Cm Pada 3 Variasi Jarak Antara Sudu Dan Saluran Keluar
}

\author{
Gibran $^{1}$, Syahril Gultom ${ }^{2}$, Zulkifli Lubis ${ }^{3}$, Pramio G. Sembiring ${ }^{4}$ \\ 1,2,3,4 Departemen Teknik Mesin, Fakultas Teknik, Universitas Sumatera Utara \\ Email: Gie_bran23@yahoo.co.id
}

\begin{abstract}
ABSTRAK
Energi pada saat sekarang ini semakin berkurang akibat penggunaan energy fosil secara berlebihan di semua bidang, Ilmuwan di seluruh dunia menyadari hal ini dan mencoba berbagai energi alternatif. Salah satu sumber energi saat ini yang banyak dilakukan penelitian adalah arus air. Indonesia adalah Negara agraris yang menghasilkan air secara terus menerus, sehingga turbin air lebih diutamakan dari turbin angin karena angin di Indonesia relatif stabil. Microhydro ataupun picohydro yang dibuat biasanya memanfaatkan air terjun dengan head jatuh yang besar, sedangkan untuk aliran sungai dengan head jatuh yang kecil dimanfaatkan dengan optimal. Hal ini menjadi referensi untuk memanfaatan aliran sungai dengan mengubahnya menjadi aliran vortex. Tujuan dari rancang bangun ini adalah untuk mendapatkan rancangan casing turbin vortex, rancangan poros, rancangan sudu dan bantalan serta bahan- yang sesuai. Turbin Vortex ini dirancang dengan debit air 0.0052 dan kecepatan air $1.44 \mathrm{~m} / \mathrm{s}$. Menggunakan casing berpenampang lingkaran berbahan Akrilik, dengan sudu berbahan seng. Dari hasil rancang bangun Turbin Vortex ini didapat efisiensi yang cukup baik, yaitu $76.01503 \%$ pada putaran $6.96033 \mathrm{rad} / \mathrm{s}$.
\end{abstract}

Kata Kunci : Energi,arus air,turbin air,head,vortex,lingkaran,akrilik.

\section{PENDAhuluan}

Energi pada saat sekarang ini semakin berkurang akibat penggunaan energi fosil secara berlebihan di semua bidang, ilmuwan diselurah dunia menyadari hal ini dan mencoba berbagai energi alternatif. Salah satu sumber energy saat ini yang banyak dilakukan penelitian adalah arus air. Penggunaan berbagai macam turbin semakin maju. Indonesia adalah negara agraris yang menghasilkan air secara terus menerus, sehingga turbin air lebih diutamakan dari turbin angin karena angin di indonesia relatif stabil. Alih fungsi turbin angin menjadi turbin air perlu dilakukan studi lebih lanjut. Massa jenis air yang hampir 1000 kali lipat massa jenis udara menyebabkan gaya dan torsi yang mempengaruhi turbin semakin besar.

Pembangkit listrik tenaga air saat ini menjadi salah satu pilihan dalam memanfaatkan sumber energi terbaru, namun pemanfaatan yang ada masih menggunakan teknologi yang sederhana. Pembangkit Listrik jenis ini dalam proses pembuatannya sangat ekonomis, tapi masih dalam skala kecil. Artinya pembangkit-pembangkit ini hanya mampu mencukupi pemakaian energi listrik untuk sejumlah rumah saja. Jenis Pembangkit Listrik Tenaga Air ini sering disebut Microhydro atau sering juga disebut Picohydro tergantung keluaran daya listrik yang dihasilkan.

Microhydro ataupun Picohydro yang dibuat biasanya memanfaatkan air terjun dengan head jatuh yang besar. Sedangkan untuk aliran sungai dengan head jatuh yang kecil belum termanfaatkan dengan optimal. Hal ini menjadi referensi untuk memanfaatkan aliran sungai dengan mengubahnya menjadi aliran vortex.

\section{TINJAUAN PUSTAKA}

\section{Pengertian Turbin Air}

Turbin air yaitu suatu mesin yang dipergunakan untuk mengamil tenaga air untuk diubah menjadi tenaga listrik, jadi berfungsi untuk mengubah tenaga air menjadi tenaga mekanis, sedangkan tenaga mekanis ini diubah menjadi tenaga listrik oleh generator. 
Turbin adalah mesin penggerak dimana energi fluida kerja dipergunakan langsung untuk memutar sudu turbin. Bagian turbin yng bergerak dinamakan rotor atau sudu turbin, sedangkan bagian yang tidak berputar dinamakan stator atau rumah turbin. Secara umum, turbin adalah alat mekanika yang terdiri dari poros dan sudu-sudu. Sudu tetap ataupun stationary blade, tidak ikut berputar bersama poros, dan berfungsi mengarahkan aliran fluida. Sedangkan sudu putar atau rotary blade, mengubah arah dan kecepatan aliran fluida sehingga timbul gaya yang memutar poros. Air biasnya dianggap sebagai fluida yang tak kompresibel, yaitu fluida yang secara virtual massa jenisnya tidak berubah dengan tekanan.

Ada beberapa kesamaan teori dari turbin air dan pompa air, dengan perbedaan utama energi transfer yang berkebalikan. Turbin air mengubah energi potensial dari air menjadi energi mekanis putaran poros. Sedangkan pompa air mengubah energi mekanis putaran poros menjadi gerak aliran air.

\section{Jenis - Jenis Turbin}

Berdasarkan prinsip kerja turbin dalam mengubah energi potensial air menjadi energi mekanis, turbin dibedakan menjadi dua kelompok yaitu turbin Impuls dan turbin Reaksi. Turbin air dibedakan menjadi dua kelompok yaitu turbin impuls dan turbin reaksi.

Sebelum berkembang menjadi turbin Pelton dan turbin Crossflow (jenis impuls), dan turbin Francis dan turbin Kaplan (jenis reaksi) seperti yang banyak ditemukan saat sekarang, beberapa jenis turbin dengan kontruksi yang relative sederhana telah mengawalinya. Di samping itu juga telah dilakukan upaya penyempurnaan dengan memodifikasi rancangan dari turbin-turbin yang sudah mapan seperti turbin Pelton, turbin Crossflow, turbin Francis, dan turbin Kaplan. Beberapa jenis turbin air dapat disebut seperti turbin Banki, turbin Fourneyron, turbin Girard, turbin Turgo, turbin Jonval, turbin Thomson, turbin Deriaz, turbin Heber, turbin Schwan-Krug. Turbin-turbin tersebut dinamakan sesuai dengan nama penemunya. Walaupun dari segi kepentingan tidak begitu besar artinya, namun dari kepentingan akademik, beberapa jenis turbin air ini perlu juga dikenal.

\section{Turbin Impuls}

Pada turbin impuls energi potensial air diubah menjadi energi kinetik pada nosel. Air keluar nosel yang mempunyai kecepatan tinggi membentur sudu tubir. Setelah membentur sudu turbin arah kecepatan aliran berubah sehingga terjadi perubahan momentum (impuls). Akibatnya roda turbin akan berputar. Turbin impuls adalah turbin tekanan sama karena aliran air yang keluar dari nosel tekananya adalah sama dengan tekanan atmosfil sekitarnya. Beberapa contoh dari turbin impuls tubin pelton dan turbin crossflow.

\section{Turbin Pelton.}

Turbin pelton merupakan turbin impuls. Turbin Pelton terdiri dari satu set sudu jalan yang diputar oleh pancaran air yang disemprotkan dari satu atau lebih alat yang disebut nosel. Turbin Pelton adalah salah satu dari jenis turbin air yang paling efisien. Turbin Pelton adalah turbin yang cocok digunakan untuk head tinggi. Berikut dibawah ini contoh gambar sudu turbin pelton.

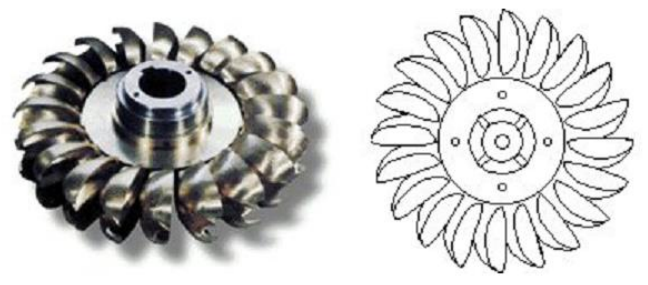

Gambar 2.1 Sudu Tubin Pelton [1]

2. Turbin Crossflow (Turbin Michell-Banki).

Pada turbin impuls pelton beroperasi pada head relatif tinggi, sehingga pada head yang rendah operasinya kurang efektif atau efisiensinya rendah. Karena alasan tersebut, turbin pelton jarang dipakai secara luas untuk pembangkit listrik skala kecil. Sebagai alternatif turbin jenis impuls yang dapat beroperasi pada head rendah adalah turbin crossflow atau turbin impuls aliran ossberger. 
Turbin crossflow dapat dioperasikan pada debit 20 litres/sec hingga $10 \mathrm{~m} 3 / \mathrm{sec}$ dan head antara $1 \mathrm{~s} / \mathrm{d}$ 200 m. Berikut dibawah ini komponen - komponen utama konstruksi turbin crossflow:

1. Rumah Turbin.

2. Alat Pengarah (distributor).

3. Roda Jalan.

4. Penutup.

5. Katup Udara.

6. Pipa Hisap.

7. Bagian Peralihan.

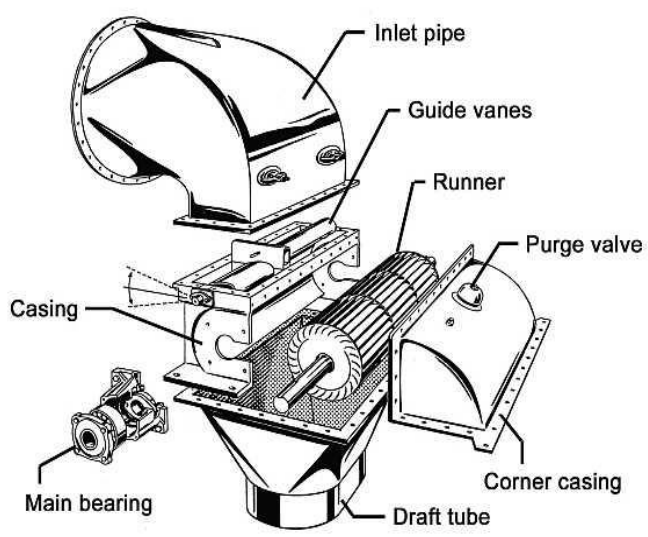

Gambar 2.2 Turbin Crossflo [2]

\section{Turbin Reaksi}

Pada turbin reaksi, energi yang tersedia pada saluran masuk hanya sebagaian saja yang dirubah menjadi energi kinetik sedangkan sisanya tetap dalam bentuk energi tekan. Ketika air mengalir melalui rod gerak/runner terjadi perubahan energi tekan menjadi energi kinetik secara berangsur-angsur. Tekanan pada sisi masuk roda gerak lebih tinggi dibandingkan tekanan pada sisi keluar roda gerak turbin, dimana tekanan tersebut bervariasi terhadap laju aliran fluida yang melalui turbin. Selanjutnya agar perubahan tekanan ini dapat terjadi, maka roda/runner dalam hal ini harus tertutup dari udara luar dan seluruhnya terisi air selama turbin beroperasi. Beberapa contoh dari turbin reaksi adalah turbin fancis, turbin kaplan, dan turbin vortex

\section{Turbin Kaplan.}

Tidak berbeda dengan turbin francis, turbin kaplan cara kerjanya menggunakan prinsip reaksi. Turbin ini mempunyai roda jalan yang mirip dengan baling-baling pesawat terbang. Bila baling-baling pesawat terbang berfungsi untuk menghasilkan gaya dorong, roda jalan pada kaplan berfungsi untuk mendapatkan gaya $\mathrm{F}$ yaitu gaya putar yang dapat menghasilkan torsi pada poros turbin. Berbeda dengan roda jalan pada francis, sudu-sudu pada roda jalan kaplan dapat diputar posisinya untuk menyesuaikan kondisi beban turbin. Turbin kaplan banyak dipakai pada instalasi pembangkit listrik tenaga air sungai, karena turbin ini mempunyai kelebihan dapat menyesuaikan head yang berubahubah sepanjang tahun. Turbin Kaplan dapat beroperasi pada kecepatan tinggi sehingga ukuran roda turbin lebih kecil dan dapat dikopel langsung dengan generator. Pada kondisi pada beban tidak penuh turbin kaplan mempunyai efisiensi paling tinggi, hal ini dikarenakan sudu-sudu turbin kaplan dapat diatur menyesuaikan dengan beban yang ada. Berikut dibawah ini komponen utama turbin kaplan:. 


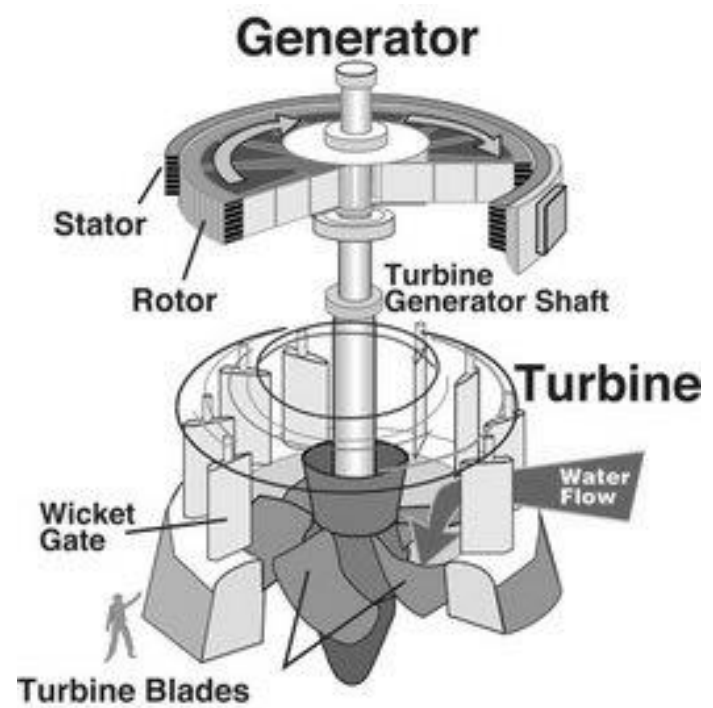

Gambar 2.3 Turbin Kaplan dengan sudu jalan yang dapat diatur [3]

\section{Turbin Francis}

Turbin francis merupakan salah satu turbin reaksi. Turbin dipasang diantara sumber air tekanan tinggi di bagian masuk dan air bertekanan rendah di bagian keluar. Turbin Francis menggunakan sudu pengarah. Sudu pengarah mengarahkan air masuk secara tangensial. Sudu pengarah pada turbin francis dapat merupakan suatu sudu pengarah yang tetap ataupun sudu pengarah yang dapat diatur sudutnya. Untuk penggunaan pada berbagai kondisi aliran air penggunaan sudu pengarah yang dapat diatur merupakan pilihan yang tepat. Berikut dibawah ini contoh gambar sudu turbin francis.

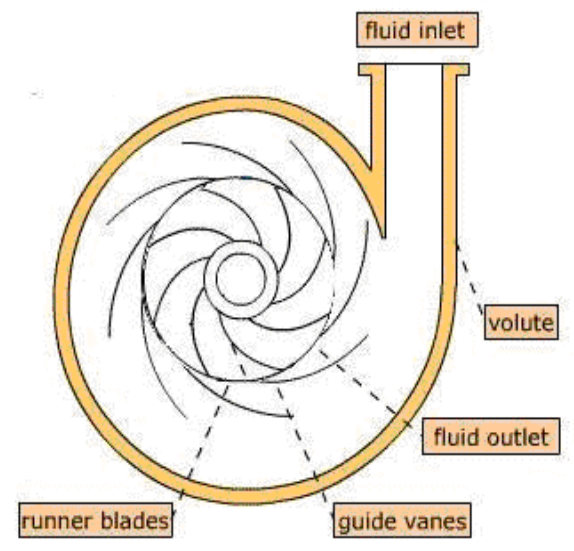

Gambar 2.4 Turbin Francis [4]

\section{Turbin Vortex (Pusaran Air)}

Turbin vortex merupakan turbin yang memanfaatkan pusaran air sebagai media perantara energi terhadap sumbu vertikal sehingga terjadi perbedaan tekanan antara bagian sumbu dan sekelilingnya. Turbin air ini dioperasikan pada daerah yang memiliki head yang rendah dan memanfaatkan pusaran gravitasi air sehingga akan menimbulkan perbedaan tekanan air dengan bagian sumbu. Hal ini ditemukan oleh insinyur Austria Franz Zotloterer ketikan mencoba untuk menemukan cara untuk menganginkan air tanpa sumber daya eksternal. Berikut dibawah ini contoh gambar turbin vortex. 


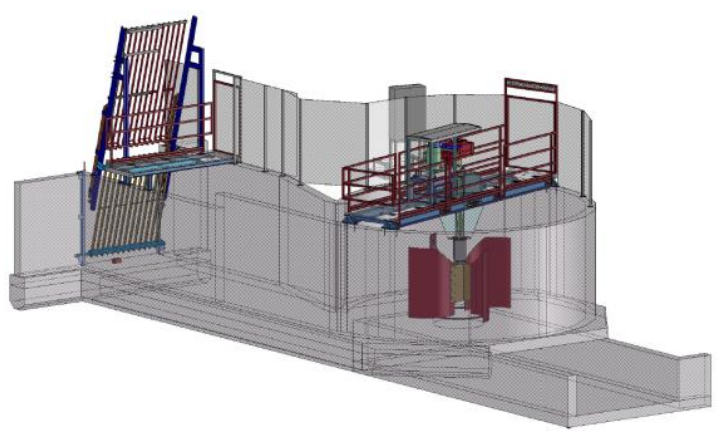

Gambar 2.5 Turbin Vortex [6]

\title{
Cara Kerja Turbin Vortex
}

Sistem PLTA pusaran air adalah sebuah teknologi baru yang memanfaatkan energi yang terkandung dalam pusaran air yang besar dengan diciptakan melalui perbedaan head rendah di sungai. Berikut dibawah ini contoh cara kerja turbin Vortex :

1. Air Sungai dari tepi sungai disalurkan dan dibawake tangki sirkulasi. Tangki sirkulasi ini memiliki suatu lubang lingkaran pada dasarnya.

2. Tekanan rendah pada lubang dasar tangki dan kecepatan air pada titik masuk tangki sirkulasi mempengaruhi kekuatan aliran vortex.

3. Energi potensial seluruhnya diubah menjadi energy kinetic rotasi diinti vortex yang selanjutnya diekstraksi melalui turbin sumbu vertikal.

4. Air kemudian kembali kesungai melalui saluran keluar.

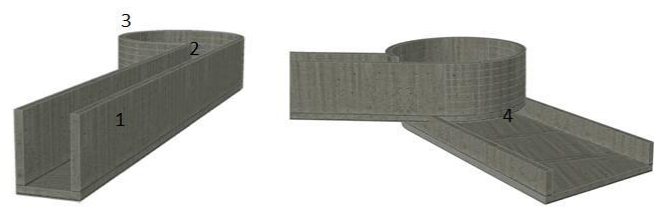

Gambar 2.6 Rumah Turbin Vortex [5]

\begin{abstract}
Aliran Vortex
Vortex adalah massa fluida yang partikel-partikelnya bergerak berputar dengan garis arus (streamline) membentuk lingkaran konsentris. Gerakan vortex berputar disebabkan oleh adanya perbedaan kecepatan antara lapisan fluida yang berdekatan. Dapat diartikan juga sebagai gerak alamiah fluida yang diakibatkan oleh parameter kecepatan dan tekanan. Vortex sebagai pusaran yang merupakan efek dari putaran rotasional dimana viskositas berpengaruh didalamnya.
\end{abstract}

\section{Aliran Vortex Bebas}

Aliran vortex terjadi walaupun tidak adanya gaya yang dilakukan pada fluida tersebut. Karateristik dari vortex bebas adalah kecepatan tangensial dari partikel fluida yang berputar pada jarak tertentu dari pusatvortex. Hubungan kecepatan partikel fluida $v$ terhadap jaraknya dari pusat putaran $\mathrm{r}$ dapat dilihat pada persamaan ini:

Dimana:

$$
V=\frac{\tau}{2 \pi r}
$$

$\mathrm{V}=$ kecepatan tangensial fluida ( $\mathrm{m} \mathrm{s}-1)$

$\mathrm{r}=$ jari-jari putaran partikel fluida dari titik pusat $(\mathrm{m})$

$\tau=$ sirkulasi 


\section{Aliran Vortex Paksa}

Apabila suatu gaya diberikan pada suatu fluida dengan maksud membuat aliran fluida berputar. Hubungan kecepatan partikel fluida $\mathrm{v}$ terhadap jaraknya dari pusat putaran $\mathrm{r}$ dapat dilihat pada persamaan berikut:

Dimana:

$$
V=r . \omega<
$$

$\omega=$ kecepatan sudut

$\mathrm{r}=$ jari-jari putaran $(\mathrm{m})$

\section{Aliran Vortex Kombinasi}

Aliran Vortex Kombinasi adalah vortex dengan vortex paksa pada inti pusatnya dan distribusi kecepatan yang sesuai dengan vortex bebas pada luar intinya. Jadi untuk sebuah votex kombinasi dapat dilihat pada persamaan berikut:

$$
\begin{array}{llll}
V_{\theta} & =\omega \mathrm{r} & r \leq r_{0} & \\
V_{\theta}=\frac{K}{r} & & \mathrm{r}<\mathrm{r}_{0}
\end{array}
$$

Dimana :

$$
\begin{aligned}
& \mathrm{K} \text { dan } \omega=\text { konstanta } \\
& \text { ro }=\text { jari-jari inti pusat }
\end{aligned}
$$

Sebuah konsep matematika yang biasanya berhubungan dengan gerakan vortex adalah sirkulasi. Sirkulasi didefenisikan sebagai sebuah integral garis dari komponen tangensial kecepatan yang diambil dari sekeliling kurva tertutup di medan aliran. Konsep sirkulasi sering digunakan untuk mengevaluasi gaya-gaya pada terbentuk pada benda-benda yang terendam dalam fluida yang bergerak.

\section{METODE PENELITIAN}

\section{Rancang Bangun Instalasi}

Rancang bangun instalasi uji eksperimental Turbin Vortex terdapat pada rooftop lantai empat Teknik Mesin USU.

Adapun elemen yang meliputi perancangan turbin vortex adalah :

\section{Rumah Turbin (casing)}

Rumah turbin berbentuk Lingkaran yang terbuat dari Akrilik dengan diameter $0,9 \mathrm{~m}$ dan tingginya $1 \mathrm{~m}$ (diukur dari saluran keluaran tempat penampungan bawah ke permukaan bak) dan memiliki lubang saluran buang pada dasar bak. Berikut dibawah ini contoh gambar casing/rumah turbin vortex.

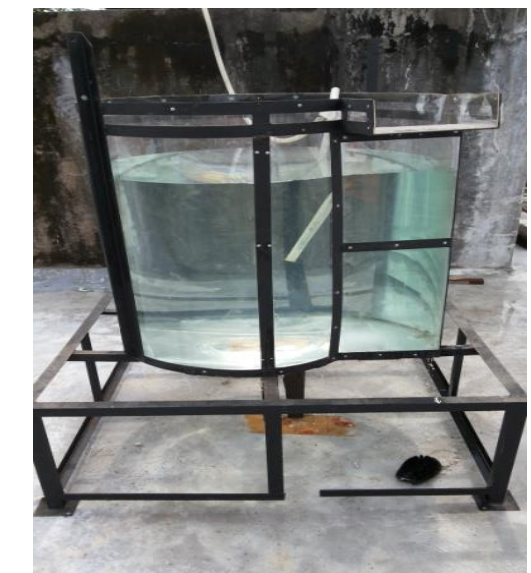

Gambar 3.1. Rumah Turbin (casing) 


\section{Poros Turbin}

Poros yang digunakan terbuat dari bahan besi S45 C-D. Dengan diameter $1,9 \mathrm{~cm}$ dan tinggi poros $1,50 \mathrm{~m}$. Berikut dibawah ini contoh gambar poros turbin vortex.

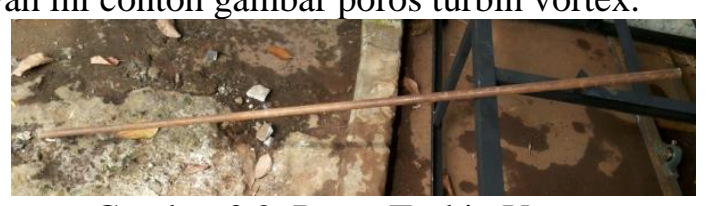

Gambar 3.2. Poros Turbin Vortex

\section{Sudu Turbin}

Sudu turbin ada 8 buah dengan tinggi sudu $\mathrm{cm} 0,9 \mathrm{~m}$ dan 3 variasi lebar sudu. Ukuran ukuran utama sudu roda jalan yang akan dihitung terdiri dari beberapa bagian yaitu:

$>$ Diameter Sudu Roda Jalan Pada Sisi Masuk

Diameter sudu roda jalan sisi masuk (D1) dan diameter roda jalan sisi keluar (D2) direncanakan adalah :

$\mathrm{D} 1=0,46 \mathrm{~m}$

$\mathrm{D} 2=0,12 \mathrm{~m}$

$\phi=30 \mathrm{o}$

\section{Jarak Antara Sudu}

Jarak antara sudu dapat ditentukan dengan persamaan :

Dimana : D1 $=$ Diameter sudu pada sisi masuk

$$
\mathrm{L}=\frac{\pi \cdot \mathrm{D}_{1}}{\mathrm{z}}
$$

maka :

$$
\mathrm{z}=\text { Jumlah sudu (direncanakan 8) }
$$

$$
\mathrm{L}=\frac{3,14 \cdot 0,32}{8}=0,12 \mathrm{~m}
$$

Tebal Sudu Roda Jalan

Sudu roda jalan dalam perancangan ditentukan dengan menggunaka bahan seng dengan ketebalan $0.20 \mathrm{~mm}$.

Tinggi Roda Jalan

Tinggi roda jalan dapat ditentukan dengan dengan persamaan :

$\mathrm{Hrj}=$ tinggi turbin - tinggi penampang

$$
=1 \mathrm{~m}-0,10 \mathrm{~m}=0,90 \mathrm{~m}
$$

Berikut dibawah ini contoh gambar sudu turbin vortex.

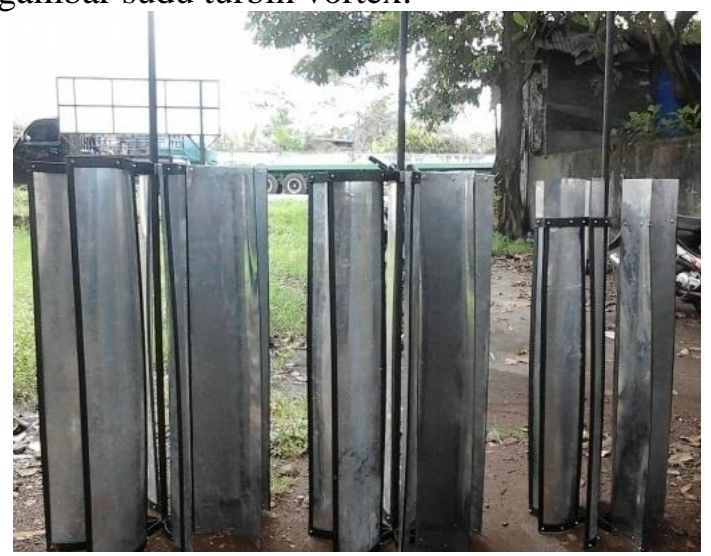

Gambar 3.3. Sudu Turbin Vortex

\section{Bantalan (bearing)}

Bantalan yang digunakan adalah P204 dengan jumlah 2 buah dan bantalan ini dibautkan di dudukan turbin. Berikut dibawah ini contoh gambar bantalan/bearing poros turbin vortex. 


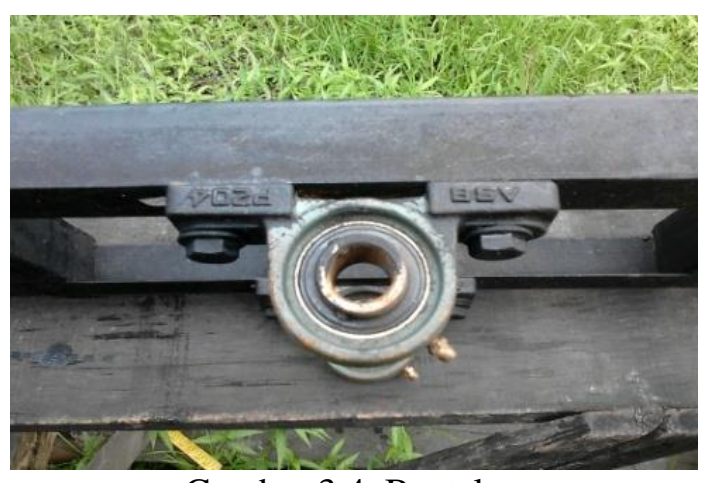

Gambar 3.4. Bantalan

\section{Dudukan Turbin}

Dudukan turbin terbuat dari besi siku yang dirangkai menggunakan las listrik. Berikut dibawah ini contoh gambar dudukan/kaki-kaki rumah turbin vortex.

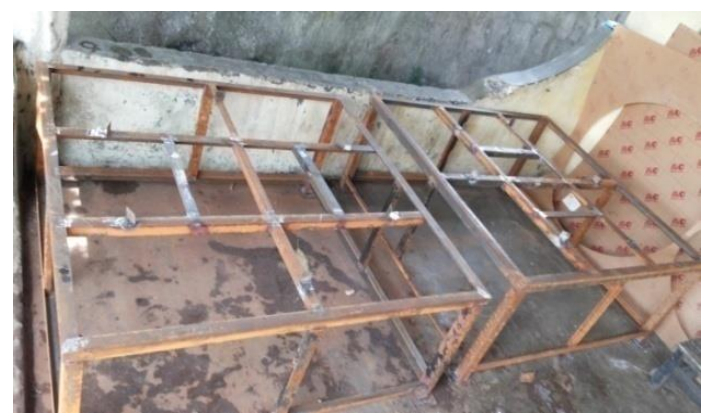

Gambar 3.5. Dudukan Turbin

\section{Saluran Buang}

Saluran buang terbuat dari akrilik dan diletakkan di bagian tengah dasar rumah turbin. Saluran buang yang digunakan adalah diameter $6 \mathrm{~cm}$. Berikut dibawah ini contoh gambar saluran keluar turbin vortex.

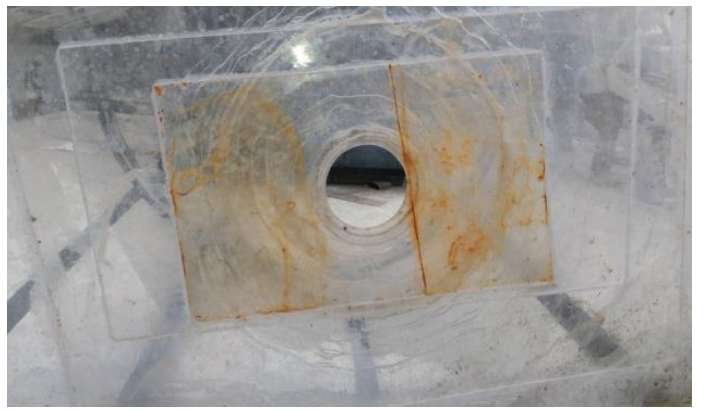

Gambar 3.6. Saluran keluar

Talang

Talang yang digunakan terbuat dari plastik dengan panjang $2 \mathrm{~m}$. Pipa yang digunakan adalah pipa 2 inchi dengan panjang keseluruhan $3,7 \mathrm{~m}$. Berikut dibawah ini contoh gambar talang turbin vortex. 


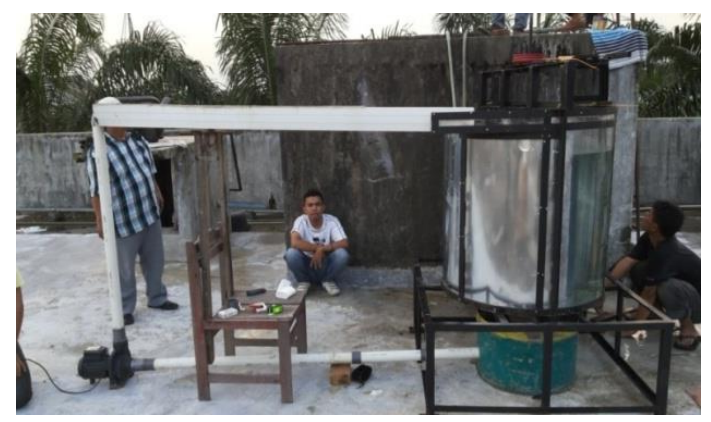

Gambar 3.7. Talang

\section{Peralatan Pengujian}

1. Hand Tachometer

2. Timbangan Pegas

3. Pulley

4. Pompa

\section{Pelaksanaan Pengujian}

Uji eksperimental turbin vortex dengan menggunakan jumlah sudu sebanyak 8 sudu dilakukan di rooftop lantai empat, Departemen Teknik Mesin, Fakultas Teknik Universitas Sumatera Utara. Pengukuran-pengukuran yang dilakukan tehadap penelitian ini meliputi:

1. Pengukuran putaran (rpm) poros turbin vortex dengan menggunakan Hand Tachometer.

2. Pengukuran momen puntir (kilogram) dengan menggunakan Timbangan Pegas.

Sebelum dilakukan pengujian turbin vortex dan pengambilan data, terlebih dahulu dilakukan pemeriksaan (checking) terhadap beberapa instalasi dan peralatan, yang meliputi:

1. Pemeriksaan debit air di dalam tempat penampungan bawah.

2. Pemeriksaan pipa penghubung antara pompa pengumpan dan talang.

3. Pemeriksaan poros turbin vortex serta pemberian pelumas pada bearing.

4. Pemeriksaan tali dan pulley.

5. Pemeriksaan pompa pengumpan.

Setelah prosedur pemeriksaan terhadap beberapa instalasi dan peralatan di atas selesai dilakukan dan pemeriksaan dipastikan dalam kondisi standby, maka prosedur pengujian pun dapat dimulai. Adapun prosedur pengujian uji eksperimental turbin vortex dengan jumlah sudu 8 adalah sebagai berikut:

1. Pengujian pertama dilakukan pada rumah turbin (casing) berpenampang Spiral dengan jumlah 8 sudu.

2. Hidupkan pompa pengumpan.

3. Dilakukan monitoring terhadap ketinggian air di dalam rumah sudu (casing).

4. Setelah ketinggian air di rumah sudu (casing) konstan, maka dilakukan pengujian serta pengambilan data terhadap:

a. Pengukuran putaran (rpm) pada poros Turbin Vortex dengan menggunakan Hand Tachometer.

b. Pengukuran momen puntir (kilogram) dengan menggunakan Timbangan Pegas.

5. Pengukuran terhadap beberapa variabel di atas dilakukan terhadap ketinggian antara sudu dengan lubang buang dengan jarak $2 \mathrm{~cm}, 4 \mathrm{~cm}$, dan $6 \mathrm{~cm}$ dengan variasi lubang buang $6 \mathrm{~cm}$.

6. Setiap pengambilan data dilakukan sebanyak sepuluh kali untuk mendapatkan data pengujian yang lebih akurat.

7. Setelah pengukuran pada turbin vortex selesai, maka dilakukan penggantian lubang buang dan rumah sudu (casing) berpenampang Lingkaran. Kemudian dilakukan pengujian kembali seperti prosedur diatas.

Besaran-besaran yang diukur dan dicatat meliputi:

1. Putaran poros Turbin Vortex (rpm)

2. Momen Puntir Turbin Vortex (kilogram)

Dari besaran-besaran di atas dapat dihitung besaran turunan lainnya seperti:

1. Torsi Turbin Vortex 
2. Daya Turbin Vortex

3. Efisiensi Turbin Vortex

\section{HASIL PENGUJIAN}

Setelah dilakukan perancangan instalasi turbin vortex dan pengujian maka diperoleh hasil pengujian sebagai berikut :

\section{Efisiensi Turbin Vortex Dengan Jarak Antara Sudu Dengan Saluran Keluar Ketinggian 2 Cm}

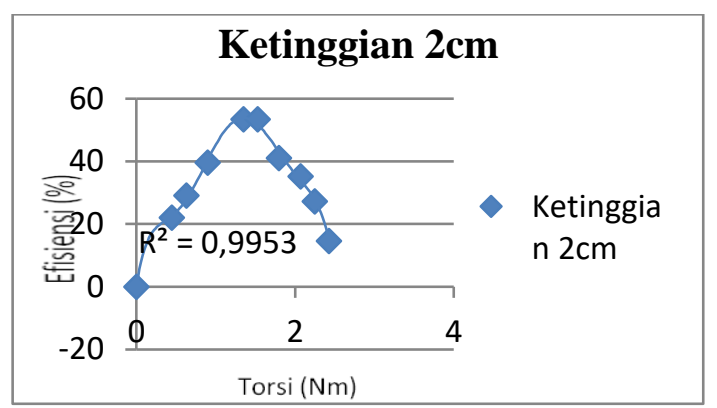

Gambar 4.1 Grafik Torsi vs Efisiensi pada jarak sudu dengan saluran keluar ketinggian $2 \mathrm{~cm}$.

Dari gambar 4.1 Torsi vs Efisiensi didapat hubungan antara Torsi dengan Efisiensi, dimana torsi yang digunakan mulai dari 0 sampai $2.43 \mathrm{Nm}$ (turbin berhenti). Dari grafik di atas didapat data bahwa efisiensi maksimum turbin vortex pada ketinggian $2 \mathrm{~cm}$ jarak antara sudu dengan lubang buang adalah sebesar $53.48138 \%$.

\section{Efisiensi Turbin Vortex Dengan Jarak Antara Sudu Dengan Lubang Buang Ketinggian 4 cm}

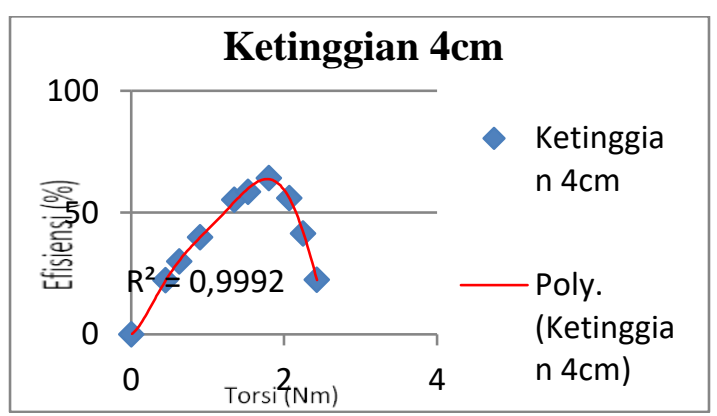

Gambar 4.4 Grafik Torsi vs Efisiensi pada jarak antara sudu dengan saluran keluar ketinggian $4 \mathrm{~cm}$

Dari gambar 4.4 Torsi vs Efisiensi di dapat hubungan antara torsi dengan efisiensi, dimana torsi yang digunakan mulai dari 0 sampai $2.43 \mathrm{Nm}$ (turbin berhenti). Dari grafik di atas didapat data bahwa efisiensi maksimum turbin vortex pada jarak antara sudu dengan lubang outlet ketinggian $4 \mathrm{~cm}$ adalah sebesar $64.21145 \%$.

Efisiensi Turbin Vortex Dengan Jarak Antara Sudu Dengan Lubang Buang Ketinggian 6 cm

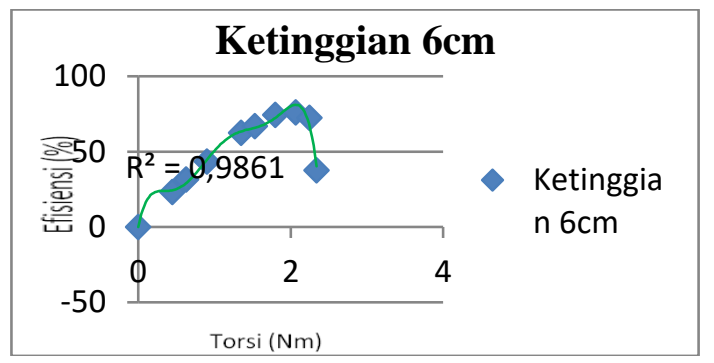

Gambar 4.7 Grafik Torsi vs Efisiensi pada jarak antara sudu dengan lubang outlet ketinggian $6 \mathrm{~cm}$ 
Dari gambar 4.7 Torsi vs Efisiensi di dapat hubungan antara torsi dengan efisiensi, dimana torsi yang digunakan mulai dari 0 sampai $2.34 \mathrm{Nm}$ (turbin berhenti). Dari grafik di atas didapat data bahwa efisiensi maksimum turbin vortex pada jarak antara sudu dengan lubang outlet ketinggian $6 \mathrm{~cm}$ adalah sebesar $76.01503 \%$.

\section{KESIMPULAN}

Dari uji eksperimental pembangkit listrik mikro hidro menggunakan turbin vortex dengan casing berpenampang Lingkaran yang menggunakan sudu berdiameter $46 \mathrm{~cm}$, Tinggi $90 \mathrm{~cm}, 3$ variasi jarak antara Sudu dan Saluran Keluar dengan Saluran Keluar berdiameter $6 \mathrm{~cm}$. Maka di dapat kesimpulan:

1. Diperoleh tingkat efisiensi maksimum yang terdapat pada jarak antara Sudu dan Saluran keluar Ketinggian $2 \mathrm{~cm}$ dengan data sebagai berikut:
a. Efisiensi Maximum $=53.48138 \%$
b. Daya Turbin $=10.13686 \mathrm{watt}$
c. Putaran Turbin $=6.6254 \mathrm{rad} / \mathrm{s}$

2. Diperoleh tingkat efisiensi maksimum terdapat pada jarak antara Sudu dan Saluran keluar Ketinggian $4 \mathrm{~cm}$ dengan data sebagai berikut:
a. Efisiensi Maximum $=64.21145 \%$
b. Daya Turbin $=12.17064$ watt
c. Putaran Turbin $=6.76146 \mathrm{rad} / \mathrm{s}$

3. Diperoleh tingkat efisiensi maksimum terdapat pada jarak antara Sudu dan Saluran keluar Ketinggian $6 \mathrm{~cm}$ dengan data sebagai berikut:
a. Efisiensi Maximum $=76.01503 \%$
b. Daya Turbin $=14.40789$ watt
c. Putaran Turbin $=6.96033 \mathrm{rad} / \mathrm{s}$

\section{DAFTAR PUSTAKA}

1. http://www.heskonenerji.com.tr/eng/teknik_bilgiler.html

2. http://www.freeflowhydro.co.uk/13/24/CINK/CINK.html

3. http://202.90.195.156/bse/smk/smk12\%20TeknikMesinIndustri\%20Sunyoto.pdz

4. http://202.90.195.156/bse/smk/smk12\%20TeknikMesinIndustri\%20Sunyoto.pdz

5. http://en.wikipedia.org/wiki/francis_turbine

6. KonzKl.EmmeRossei_110131[1].doc / WWK Energie GmbH

7. M.M Dandekar dan K.N. Sharman, "Pembangkit Listrik Tenaga Air". UI-Press, Jakarta,1991.

8. Rajput Rames, "A Textbook of Fluida Mechanics and Hydraulic Machine", Part-II, Rajput. Company, 2000.

9. Sularso, Kiyokatsu Suga,'Dasar Perencanaan dan Pemilihan Elemen Mesin", Cetakan kesepuluh, Pradnya Paramitha, Jakarta, 2002.

10. Victor.L.Streeter and Benjamin, "Mekanika Fluida", Erlangga, Jakarta, 1993.

11. Warnik,C.C, "HydroPower Engineering", Prentice Hall, Inc, New York,1989.

12. http://www.ceb.cam.ac.uk/pages/ofm-facilities-and-equipment.html

13. http://www.zotloeterer.com/

14. http://yusufrandabunga.wordpress.com/2012/04/29/turbin-vortex/

15. http://eprints.unsri.ac.id/100/1/PROSIDING_AVOER_2011kafrawi.pdf

16. http://www.telimek.lipi.go.id/xdata/docs/ELDA22.pdf

17. http://www.slideshare.net/khairul_fadli/perencanaan-turbin-air

18. http://elista.akprind.ac.id/fti/jurnal_teknologi/volume_1_edisi_1/hal-9-13-taufik1.pdf 